\title{
Interactive comment on "Excess nitrogen as a marker of intense dinitrogen fixation in the Western Tropical South Pacific Ocean: impact on the thermocline waters of the South Pacific" by Alain Fumenia et al.
}

Alain Fumenia et al.

alain.fumenia@mio.osupytheas.fr

Received and published: 18 October 2018

The comment was uploaded in the form of a supplement:

https://www.biogeosciences-discuss.net/bg-2017-557/bg-2017-557-AC1-

supplement.pdf 